Rechtsmedizin $2020 \cdot 30: 451-457$ https://doi.org/10.1007/s00194-020-00426-9 Published online: 25 September 2020 (C) The Author(s) 2020

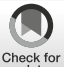

\author{
K. Jellinghaus' $\cdot$ S. Matin 1 P. Urban ${ }^{1,2} \cdot$ M. Bohnert ${ }^{1} \cdot$ R. Jantz ${ }^{3}$ \\ ${ }^{\prime}$ Institute of Forensic Medicine, Julius-Maximilians-University, Würzburg, Germany \\ ${ }^{2}$ Institute of Biological Anthropology, Medical Center, Albert-Ludwigs-University, Freiburg im Breisgau, \\ Germany \\ ${ }^{3}$ Department of Anthropology, University of Tennessee, Knoxville, USA
}

\title{
Study of the K-S distance on skulls from different modern populations for sex and ancestry determination
}

have been observed among different ancestralities, which could be due to genetic or environmental influences [3].

Lovejoy et al. [8] reported in 1985 on the use of occlusion of the sutures on the pterion for age and sex determination in archaeological and forensic skeletal remains. In the pterion two landmarks are defined according to Knussmann [9]: the sphenion as the anterior end point of the sphenoparietal suture and the krotaphion as theposterior end point of the sphenoparietal suture (• Fig. 1).

Pterion's morphological variability in various ancestral populations and between the sexes is known; however, in most studies, no quantitative analysis of morphological features has been performed, and thus the pterion has not been used as a morphometric method of differentiation for sex and ancestry. The aim of our study was to find out if the distance of the landmarks sphenion and krotaphion of four different populations were suitable for the following:

1. a sexual differentiation of skulls of modern German individuals among themselves,

2. for an ancestral differentiation of the examined skulls (African-American, Rwandan, Euro-American and German) among themselves.

In our study the term "modern" concerning the examined skulls is defined as skulls from the nineteenth century onwards. This definition is to be seen from the anthropological perspective and is not comparable with the established forensic definition of "modern" which includes skeletal remains with a post-mortem interval of up to 100 years.

\section{Material and methods}

\section{Skull collections}

Our dataset contained a total of 637 male and 341 female skulls, derived from four different populations (see Matin [10] for additional information).

\section{German skulls}

The studied 149 German skulls were mainly derived from three skull collections:

1. Würzburg: 5 skulls came from the Institute of Legal Medicine of the University of Würzburg. The skulls had been recovered from cemeteries in the surroundings of Würzburg.

2. Munich: 101 skulls came from a skull collection from the Institute of Legal Medicine in Munich. These were primarily forensic cases from the Munich area that were accumulated and are now in the possession of the institute. Name, place of birth and other biographical details were documented for every skull in mortuary books.

3. Tübingen: 43 skulls came from the anatomical skull collection from the archaeological institute in Tübingen. frontozygomatic suture [7]. Differences
regarding the location of the pterion 


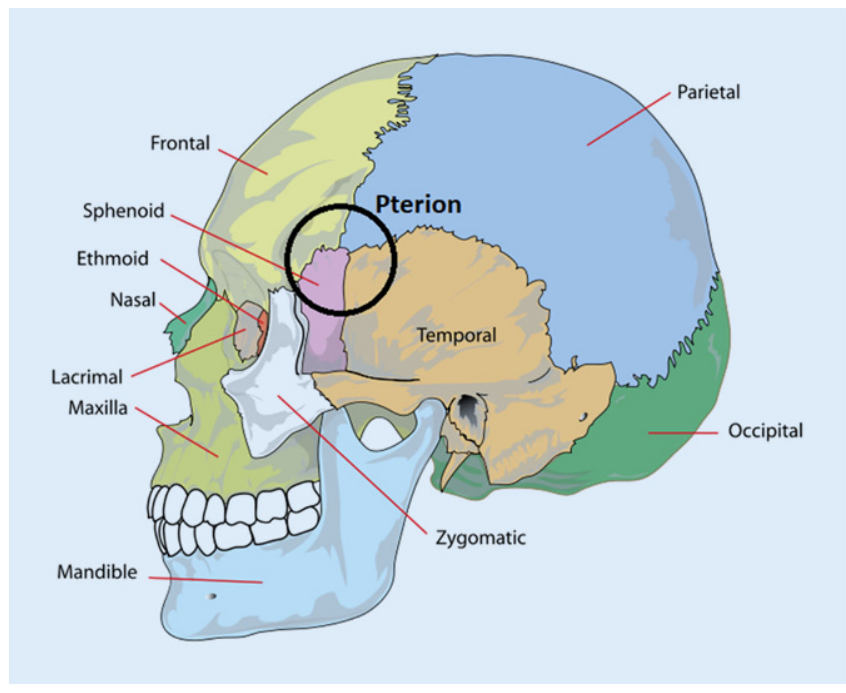

Fig. $1 \varangle$ Pterion on the human skull in the lateral view (source https://commons. wikimedia.org/ wiki/File:Human skull_side simplified_(bones). svg, Author Mariana Ruiz Villarreal)
This collection originally belonged to the anatomy department and is now in the possession of the Institute of Natural Archaeology of the University of Tübingen. Many of the skulls were forensic cases or executions. Name, place of birth and other biographical details were documented for every skull.

Calculating the K-S distance was not possible for all German skulls: from 89 skulls either one or both K-S distances could be calculated. All German skulls dated from the period from 1801 to 2000, 61 were male, 28 were female, the age of the decedents was between 6 and 92 years with a mean of 48.79 years.

\section{American skulls}

The K-S distances were provided by Prof. Jantz. The American skulls were divided into 2 groups:

1. African-Americans-124 skulls in total; 73 males, 51 females, aged from 19 to 72 years with a mean age of 43.4 years, dating from the period 1866-1972.

2. Euro-Americans-664 skulls in total; 439 male, 225 female, aged 18-85 years with a mean age of 43.4 years, dating from the period 1925-1974.

\section{Rwandan skulls}

The K-S distances were provided by Prof. Jantz. The skulls originate from Rwanda from the late nineteenth century and were brought to Germany in 1907-1908 by the anthropologist Jan Czekanowski, who was engaged by Felix von Luschan to lead the expedition. Today, the skulls are part of the collection of the Berlin Society for Anthropology, Ethnology and Prehistory.

Number of Rwandan Skulls: 98 in total; 61 male, 37 female, aged 15 to 60 years with a mean age of 40.15 years, dating from the period 1846-1891.

\section{Data acquisition}

Skulls were only included in the dataset if a defect on the bone had not led to any distortion of the entire skull, if sex, origin, age or year of birth, year of death, country of birth of the skull were known and if the distance between sphenion and krotaphion was calculable. Every skull underwent a measuring process described hereafter, which was the same for all data of the skulls used for our study. Experience of both anthropologists and forensic pathologists show that digital data acquisition using technique, such as a $3 \mathrm{D}$ digitizer is to be superior concerning intraand inner observer errors.

The first step of the measurement process was the inspection of the skull. Any

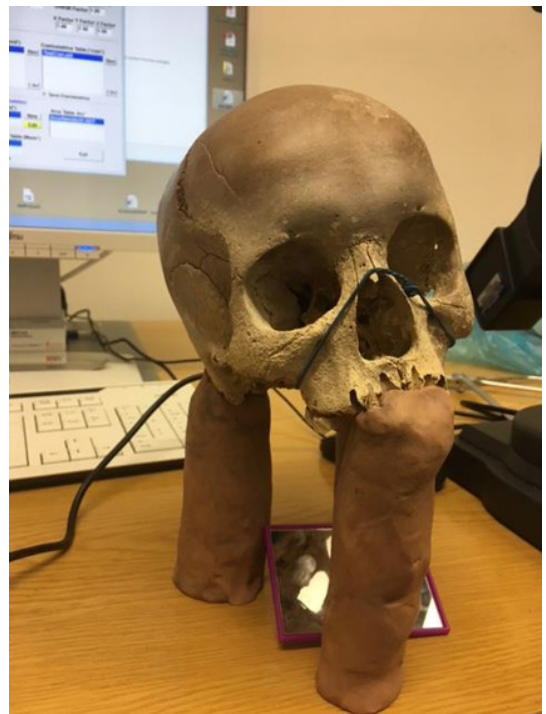

Fig. $2 \Delta$ Fixation of the skull using modelling clay

defects on the skull were to be documented, especially those that led to distortions and shifts of landmarks. The data of the skulls (sex, age, origin and year of death) were investigated in mortuary books as well as inventory lists and further registered. The landmarks were marked with a pencil on the surface of the bone and the whole skull was afterwards fixed on three columns of modelling clay on a table. The digital acquisition took place with a Microscribe 3-D digitizer (RSI 3D-Systems, Oberursel, Germany) with a multijointed arm: Microscribe digitizers are routinely used in 3D measurement technology among many fields to capture geometric characteristics of objects. The stylus allows the user to quickly trace over the contours of a physical object with ease to obtain quick 3D measurements. Using the Microscribe we captured points in the 3 spatial axes, relative to the zero position of the arm. After acquiring all values, a 3-D reconstruction and a measurement of the distances between individual landmarks were possible. Digital data acquisition was done using the software 3Skull (The software was produced by Steve Ousley from the University of Tennessee, Department of Anthropology in 2014), which was able to calculate the distance between different landmarks by the measured coordinates.

- Figs. 2 and 3 show fixation and measuring of the skull. 


\section{Statistical methods}

Since there were exact $\mathrm{X}, \mathrm{Y}$ and $\mathrm{Z}$ coordinates for each measurement point acquired by Microscribe and 3Skull, the distance between the landmarks krotaphion and sphenion was determined by calculating the Euclidean distance between the two points. The formula for calculating the Euclidean distance between 2 points ( $\mathrm{dP} 1, \mathrm{P} 2)$ is as follows:

$$
\begin{aligned}
& \mathrm{d} P_{1}, P_{2}= \\
& \sqrt{(\mathrm{x} 2-\mathrm{x} 1)^{2}+(\mathrm{y} 2-\mathrm{y} 1)^{2}+(\mathrm{z} 2-\mathrm{z} 1)^{2}}
\end{aligned}
$$

Afterwards, the following statistical analyses were carried out with the data acquired:

- Shapiro-Wilk test for testing if a random sample comes from a normal distribution. Small "W" values indicate the sample is not normally distributed.

- Levene's test and t-test for judging the differences of the krotaphionsphenion distance between the sexes, both for the left and right sides of the skull (Levene's test is used for nonnormal distributions to check that variances are equal for all samples; the T-test is used when comparing two independent groups to see if their means are different).

- ANOVA to determine whether there are any statistically significant differences between the means of the independent (unrelated) groups.

- Welch test two-sample location test used to test the hypothesis that two populations have equal means.

- Brown-Forsythe test statistical test for the equality of group variances based on performing an ANOVA on a transformation of the response variable.

- Tukey HSD test used to determine if the relationship between two sets of data is statistically significant.

- Games-Howells test nonparametric approach to compare combinations of groups or treatments that does not assume equal variances and samples.

Rechtsmedizin 2020 · 30:451-457 https://doi.org/10.1007/s00194-020-00426-9

(c) The Author(s) 2020

K. Jellinghaus · S. Matin · P. Urban · M. Bohnert · R. Jantz

\section{Study of the K-S distance on skulls from different modern populations for sex and ancestry determination}

\section{Abstract}

In forensic science determination of the origin and sex of skeletal remains is an important task for identification purposes. In this study we investigated the krotaphionsphenion distance ( $\mathrm{K}-\mathrm{S}$ distance) in the pterion region of German, Euro-American, African-American and Rwandan skulls of modern individuals from the nineteenth to the twenty-first century to look for statistically significant differences in sex and ancestry. We found a statistically significant sex-specific difference in the K-S distance, which was greater in male skulls than in female skulls for both sides of the skull. Our study also showed that there is a statistically significant difference in the K-S distance between the four populations studied. Landmarks and morphometric parameters measured in our investigations, which were not used for the present examination were provided to the software program Fordisc for its reference data to enhance the range of its usability for identification of unknown skulls or partial skulls of European individuals.

Keywords

Forensic anthropology · Forensic osteology . Identification · Gender · Landmarks

\section{Untersuchung der K-S-Distanz an Schädeln unterschiedlicher moderner Populationen zur Bestimmung von Geschlecht und Ethnie}

\section{Zusammenfassung}

Bei der forensischen Begutachtung zur Identifizierung unbekannter Skelettfunde spielen Herkunftsanlaysen und Geschlechtsbestimmungen eine bedeutende Rolle. In unserer Studie an euroamerikanischen, afroamerikanischen, ruandischen und deutschen Schädeln untersuchte unsere Arbeitsgruppe die sog. KrotaphionSphenion-Distanz in der Pterion Region am menschlichen Schädel, um geschlechts- und herkunftsspezifische Unterschiede näher zu beleuchten. Unsere Ergebnisse zeigen einen signifikanten Unterschied in der K-S-Distanz: Männliche Individuen zeigten auf beiden Seiten des Schädels signifikant größere Werte als weibliche Individuen, des Weiteren waren signifikante Unterschiede unter den vier untersuchten Populationen festzustellen. Die weiteren, im Rahmen der Studie gemessenen, jedoch für die vorliegende Auswertung nicht verwendeten Landmarken und morphometrischen Parameter der Schädel gingen in die Datenbank für die Identifizierungs-Software Fordisc ein, um deren Datengrundlage und damit Nutzbarkeit zur Identifikation unbekannter Schädel oder Schädelteile europäischer Individuen zu verbessern.

\section{Schlüsselwörter}

Forensische Anthropologie · Forensische Osteologie · Identifizierung · Geschlechtsbestimmung $\cdot$ Landmarken

\section{Results}

\section{Mean value krotaphion-sphenion distance}

A comparison of the mean values of the krotaphion-sphenion distance showed that there was certain symmetry in all groups, since the mean values of the two sides were close to each other (• Table 1 ).

The smallest average value was found among the Rwandan population (left $8.73 \mathrm{~mm}$, right $8.70 \mathrm{~mm})$. The biggest average value of the krotaphion-sphenion distance was found on the left side among the German skulls $(15.64 \mathrm{~mm})$.

The analysis with the Shapiro-Wilk test for normal distribution showed the following distribution:

Left krotaphion-sphenion distance:

Normal distribution:

- Euro-American skulls $(p=0.067$, $p>0.05$ )

- Rwandan skulls $(p=0.072, p>0.05)$

- German skulls $(p=0.701, p>0.05)$ 


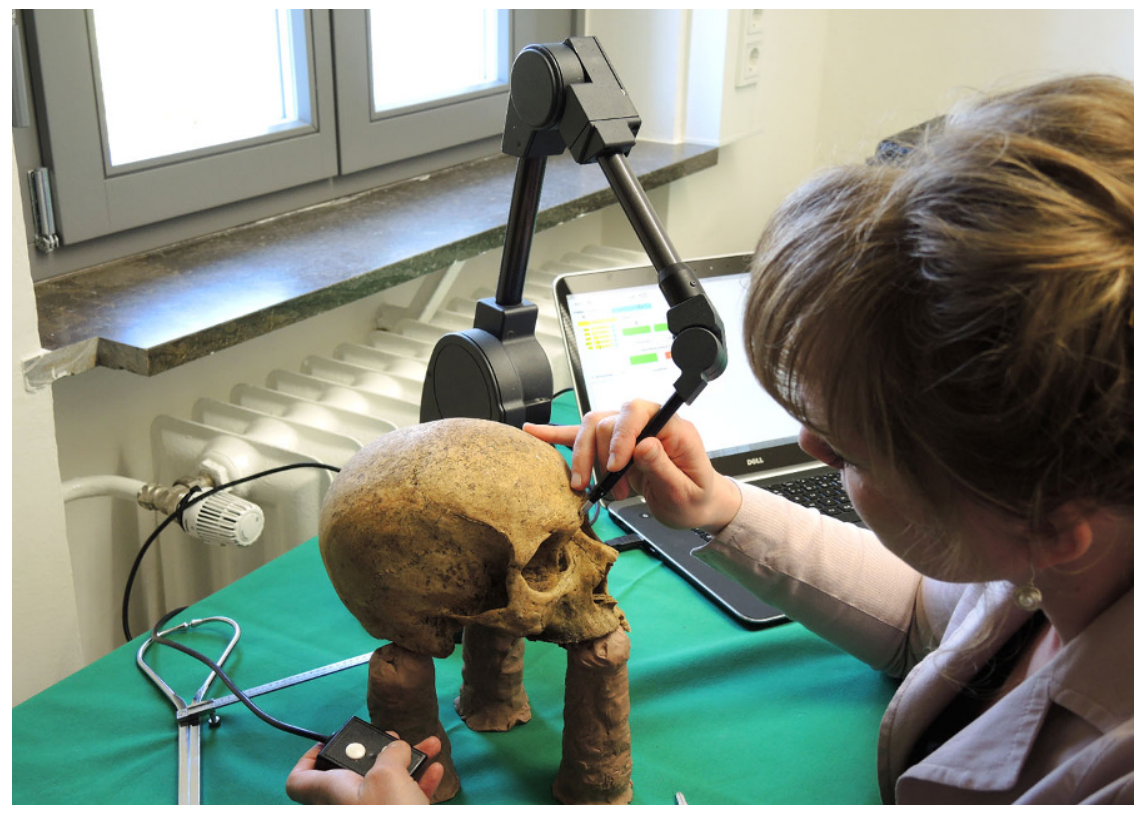

Fig. $3 \Delta$ Measuring process with the 3D digitizer

Non-normal distribution:

- African-American skulls ( $p=0.035$, $p<0.05$ )

Right krotaphion-sphenion distance:

In the Shapiro Wilk test of the right K-S distance, only the German population was found to be normally distributed with a $p$-value of 0.18 . The $p$-value in the remaining 3 populations was $<0.05$; the distribution of these three populations differed significantly from a normal distribution.

\section{Sex comparison}

Independent samples T-test:

In our dataset containing a total of 634 male and 341 female skulls, the mean krotaphion-sphenion distance of the left side was larger in male skulls $(14.17 \mathrm{~mm})$ than in female skulls $(13.27 \mathrm{~mm})$. The median krotaphion-sphenion distance on the right side was also larger in male skulls $(13.52 \mathrm{~mm})$ than in the female skulls $(12.53 \mathrm{~mm})$.

For investigating sex differences, Levene's test and the T-test were performed. Levene's test assumed that variances were homogeneous and there was no statistically significant difference between the groups. The F value of the test for the left side of the skull was 0.51 and the significance value was 0.82 , which was higher than a $P$-value of 0.05 . This means that the variances are homogeneous. The $\mathrm{T}$ value was 2.548 with a $P$-value of 0.011 , which was smaller than the error probability of 0.05 . Thus, the differences in the krotaphion-sphenion distance between the two sex groups were statistically significant.

- Table 2 shows that the F value of the Levene's test was large (2.038) with a significance value of 0.154 and the variances were homogeneous.

The T-test gave a value of 2.917 with a $P$-value of 0.004 , which was less than the significance level of 0.05 . Thus, there was a statistically significant difference between the two sex groups in the krotaphion-sphenion distance.

\section{Ancestral differences: left krotaphion-sphenion distance}

The ANOVA test of the left krotaphionsphenion distance resulted in an F-value of 66.230 , with a $P$-value below the 0.05 limit, demonstrating a statistically significant difference between the ancestral groups; however, the assumption of homogeneity for the ANOVA analysis as tested by the Levene's test was not met. Therefore, the ANOVA results were statistically not robust enough.

The two tests that do not make any assumptions about the variances or allow heterogeneity of the variances of each group are the Welch test and the BrownForsythe test: these tests also showed a statistically significant difference for the left krotaphion-sphenion distance.

All three test methods showed that there was difference between the groups, but not where exactly this difference was to be found or which group was different from the others. To test these differences, two post hoc tests were performed:

1. Tukey HSD:

Test results were as follows ( $P$-value $<0.05)$ :

- African-American skulls were different from all three other populations.

- Euro-American skulls were different from Rwandan and AfricanAmerican skulls, but not from the German skulls.

- German skulls were different from Rwandan and AfricanAmerican skulls, but not from Euro-American skulls.

- Rwandan skulls were different from all three other populations.

2. Games-Howells test $(P$-value $<0.05)$ :

- African-American skulls were different from all three other populations.

- Euro-American skulls were different from African-American skulls and Rwandan skulls, but not from German skulls.

- German skulls were different from African-American skulls and Rwandan skulls, but not from Euro-American skulls.

- Rwandan skulls were different from all three other populationsg.

\section{Ancestral differences: right krotaphion-sphenion distance}

Levene's test showed a $P$-value $>0.05$ for the right krotaphion-sphenion distance. Therefore, there was no inequality between the variances of the individual groups. The results of the analysis of variance returned an F-value of 45.11 with a $P$-value $<0.05$. Therefore, there was a statistically significant difference between the ancestral groups. The assumption of homogeneity for the ANOVA analysis as tested by the Levene's test was 
Table 1 Comparison of mean values of krotaphion-sphenion distances of left and right sides in the skulls from the different population groups (in $\mathrm{mm}$ )

\begin{tabular}{|l|l|l|}
\hline & $\begin{array}{l}\text { Mean value krotaphion- } \\
\text { sphenion distance left }\end{array}$ & $\begin{array}{l}\text { Mean value krotaphion- } \\
\text { sphenion distance right }\end{array}$ \\
\hline African-American & 11.03 & 11.19 \\
\hline Rwandan & 8.73 & 8.70 \\
\hline Euro-American & 14.90 & 14.04 \\
\hline German & 15.64 & 14.46
\end{tabular}

met. The ANOVA results were now statistically robust enough.

The Welch and Brown-Forsythe tests also showed statistically significant difference between the ancestral groups with a $P$-value $<0.05$ for the right krotaphionsphenion distance.

As for the left krotaphion-sphenion distance, the Tukey HSD and the GamesHowells tests as post hoc tests were performed for the right side of the skull:

1. Tukey HSD; the test results were as follows $(P$-value $<0.05)$ :

- African-American skulls were significantly different from all three other populations.

- Euro-American skulls were significantly different from AfricanAmerican skulls and Rwandan skulls, but not German skulls.

- German skulls were significantly different from African-American skulls and Rwandan skulls, but not from Euro-American skulls.

- Rwandan skulls differed significantly from all three other populations.

2. Games-Howells test; the test results were as follows $(P$-value $<0.05)$ :

- African-American skulls were significantly different from all three other populations.

- Euro-American skulls were significantly different from AfricanAmerican skulls and Rwandan skulls, but not German skulls.

- German skulls were significantly different from African-American skulls and Rwandan skulls, but not from Euro-American skulls.

- Rwandan skulls differed significantly from all three other groups.

\section{Discussion}

In our study skulls from four different populations were compared: 1) Germans 2) Euro-Americans 3) African-Americans and 4) Rwandans. The analysis of the data was supposed to show whether there were sex-specific and/or ancestry-specific differences in the documented krotaphion-sphenion distances within the four populations. Additional landmarks and morphometric parameters captured will be provided to Fordisc to enhance the range of its usability for identification of unknown European skulls.

\section{Sex differentiation}

The examined krotaphion-sphenion distance in our study showed a statistically significant sex-specific difference and was greater in male skulls than in female skulls. This trend was observed on both sides of the skull; on the left side there was a mean distance of $14.2 \mathrm{~mm}$ for male skulls and only $13.3 \mathrm{~mm}$ for female skulls. The krotaphion-sphenion distance on the right side was smaller overall, so that a pure comparison of the mean values showed an asymmetry. The T-test showed a statistically significant difference between the sexes on the left side. Both the right and the left krotaphion-sphenion distances were $1 \mathrm{~mm}$ longer among male skulls than female skulls (male $13.5 \mathrm{~mm}$, female $12.5 \mathrm{~mm}$ ). In the T-test a statistically significant difference between the sexes was also shown on the right side of the skull. Assuming that the krotaphion-sphenion distance can be used as a measurement of skull size, the data are consistent with the general assumption that male skulls are larger and more robust than female skulls $[11,12]$.
Our results reflect the frequency of the sphenoparietal variant, which the anthropological researcher Murphy had already found in his morphological analysis on skulls of Aborigines: Murphy performed his study to thoroughly analyze pterion types and correlation with cranial indices, but without looking for gender or ancestral differences. A relevant difference to our study is that for quantitative analyses Murphy included all variants of the pterion region in the study except the epipteric variant. The distribution of his results showed two maxima: the first peak in the distribution curve was between $+4 \mathrm{~mm}$ and $+9 \mathrm{~mm}$, the second peak was between $-11 \mathrm{~mm}$ and $-6 \mathrm{~mm}$ in the frontotemporal variant. On average, the krotaphion-sphenion distance in the frontotemporal variant was $11.2 \mathrm{~mm}$ long with a standard deviation of $4.2 \mathrm{~mm}$. Murphy explained the distribution with two maxima either with an inhomogeneous data set or with a still unknown factor, which led to a preponderance of the frontotemporal variant with a krotaphion-sphenion distance of $8-11 \mathrm{~mm}$ [13]. By comparing the results of Murphy to ours, the different ethnic evolution of both Aborigines and the other examined populations, such as AfricanAmericans has to be considered. Nevertheless, the average krotaphion-sphenion distance presented by Murphy matches the average distance that the AfricanAmericans showed in our study (right side: $11.19 \mathrm{~mm}$ with SD $5.15 \mathrm{~mm}$; left side: $11.03 \mathrm{~mm}$ with SD $4.95 \mathrm{~mm}$ ).

\section{Ancestral differentiation}

In terms of ancestry differences, the skulls of the German population showed the greatest asymmetry; the mean for the krotaphion-sphenion distance was $15.6 \mathrm{~mm}$ on the left and $14.5 \mathrm{~mm}$ on the right, a difference of $1.2 \mathrm{~mm}$. The Rwandan population had the smallest mean krotaphion-sphenion distance with a mean of $8.7 \mathrm{~mm}$ left and right, showing the strongest symmetry with respect to the krotaphion-sphenion distance. This agrees with literature so far as the occurrence of the frontotemporal variant of the pterion is highest among African populations [14]. Asala and Mbajiorgu 


\begin{tabular}{|c|c|c|c|c|c|c|c|c|c|c|}
\hline \multirow[t]{3}{*}{$\begin{array}{l}\text { K-S- } \\
\text { Distance }\end{array}$} & \multirow[t]{3}{*}{$\begin{array}{l}\text { Equal } \\
\text { variances }\end{array}$} & \multicolumn{2}{|c|}{$\begin{array}{l}\text { Levene's test for } \\
\text { equality of vari- } \\
\text { ances }\end{array}$} & \multicolumn{7}{|c|}{ T-test for equality of means } \\
\hline & & & \multirow[t]{2}{*}{$\begin{array}{l}\text { Signifi- } \\
\text { cance }\end{array}$} & \multirow[t]{2}{*}{$\mathbf{T}$} & \multirow[t]{2}{*}{ Df } & \multirow[t]{2}{*}{$\begin{array}{l}\text { Sig. } \\
\text { (2-sided) }\end{array}$} & \multirow[t]{2}{*}{$\begin{array}{l}\text { Average } \\
\text { difference }\end{array}$} & \multirow{2}{*}{$\begin{array}{l}\text { Difference } \\
\text { standard } \\
\text { error }\end{array}$} & \multicolumn{2}{|c|}{$\begin{array}{l}95 \% \text { confidence interval } \\
\text { of the difference }\end{array}$} \\
\hline & & & & & & & & & Lower & Upper \\
\hline \multirow[t]{2}{*}{ Left side } & Assumed & 0.051 & 0.822 & 2.548 & 973 & 0.011 & 0.89657 & 0.35191 & 0.20598 & 1.58717 \\
\hline & $\begin{array}{l}\text { Not as- } \\
\text { sumed }\end{array}$ & - & - & 2.545 & 693.950 & 0.011 & 0.89657 & 0.35227 & 0.20493 & 1.58822 \\
\hline Right side & Assumed & 2.038 & 0.154 & 2.917 & 973 & 0.004 & 0.99508 & 0.34112 & 0.32566 & 1.66450 \\
\hline- & $\begin{array}{l}\text { Not as- } \\
\text { sumed }\end{array}$ & - & - & 2.991 & 747.541 & 0.003 & 0.99508 & 0.33266 & 0.34203 & 1.64813 \\
\hline
\end{tabular}

postulated that the frequency of frontotemporal articulation, in combination with other non-metric parameters, could be used as a distinguishing feature of African descent [15]. Hauser and De Stefano [16] summarized the frequencies of the frontotemporal variant of different populations: The most common incidence of the frontotemporal variant was found in Melanesians (present day New Guinea, New Caledonia and Solomon Islands) and African populations. The lowest incidence was found in European populations (British, Dutch, Italian).

The ANOVA analysis performed in our study showed a statistically significant difference between the individual populations in the krotaphion-sphenion distance, both on the left and the right side of the skull. In further analyses (Tukey HSD and Games-Howells tests), it can be stated that the African-American and Rwandan populations differed from all other groups. The German and Euro-American populations differed only from the Rwandan and AfricanAmerican populations. This trend could be observed on the right and left side and is further supported by the fact that although the African-American populations are very heterogeneous in modern times; African-American descent can be primarily attributed to the African continent [17]. Thus, the analysis indicates that there is less difference between the African-American and Rwandan populations than between African-Americans and Germans or between Rwandans and Germans. Additionally, we saw less differences between German and Euro-
American populations than between Germans and African-Americans or Rwandans.

In summary we can state that our study showed a statistically significant difference in the krotaphion-sphenion distance between the four populations studied.

\section{Krotaphion-sphenion distance}

Morphometric analysis of the pterion region has so far rarely been reported in the literature; in consequence no suitable comparative data were available for our study. Vivaan et al. examined 78 skulls from an Indian population from the Institute of Anatomy in Begaluru (India) capturing the krotaphion-sphenion distance by digital measuring. Here, a mean distance of $14.06 \mathrm{~mm}$ and $14.58 \mathrm{~mm}$ was determined for each of the right and left sides. Further analyses of the statistical differences between sex or other populations were not performed in the study [18]. While interpreting these results in comparison to ours, they are nearest to our measured data from Euro-American and German skulls. As an attempted explanation for this, many factors next to historical components have to be taken into account: in general, both genetics and environment have an impact on cranial morphology. The exact control mechanisms for formation of the different variants of pontic stenosis, asymmetry, sex and ancestry-specific differences in krotaphion-sphenion distance are still not exactly known. For a population limited to a particular geographical area, there have to be different factors influ- encing growth and development of the skull; however, there is a closely linked genetic component [19] as morphological skull characteristics are inherited and thus cause ancestry-specific differences. Abbie [20] showed the human skull as a physical mosaic of independent inherited traits. The mosaic for each ancestral group is determined by its own genetic pool. Liu etal. for example discovered the MSX2 gene, which encodes a transcription factor and is active in craniofacial morphogenesis, especially at cranial sutures. Overexpression of this gene led to early occlusion of the cranial sutures and thus deformation of the skull [21]. Furthermore, the development of the neurocranium strongly correlates with the growth of the brain and is dependent on interactions between different types of tissue involved in the sutures [22].

\section{Limiting factors}

Limiting factors of our study are the following points:

- We only analyzed morphometric as well as non-morphological features on the skulls; further configuration of the cranial sutures in the pterion region was not examined. If a special anatomical variant was present on the pterion region, the measurement on the skull was ignored so that the analysis was based only on the standard variant (the classical " $\mathrm{H}$ " form) of the sphenoparietal suture. Therefore, the interpretation of the results is limited because they cannot 
be applied to any special variants in the pterion region.

- The data set used for this study is not to be considered as modern in the forensic point of view. Medical imaging becomes more and more important in forensic medicine today, in consequence cranial CT images could be a more suitable item for future examinations while acquiring really modern (present day) morphometric cranial data.

- In many cases of found unknown skeletal remains only one pterion region or even none could be measured. The investigated anatomical feature of the pterion is to be seen as a very specific possibility for identifying inviduals. The method has a limited radius so that it can not be offered to criminal authorithies.

\section{Conclusion}

All humans are members of a single species; genetic diversity is very large within human populations, and human genetic variation should be perceived as a continuum rather than an isolated event; however, in the field of forensic osteology, determination of origin and sex is helpful in identifying unknown human remains. In summary, our study has shown statistically significant differences in the krotaphionsphenion distance among the analyzed skulls. A statistically significant difference was also found between the two sexes analyzed.

Sex and origin differentiation on an isolated skull performed by combined evaluation of known morphological or morphometric parameters is superior to discrimination based on the single measurement of the krotaphion-sphenion distance. It can, however, be useful in doubtful cases, especially if only remnants of the skull are present.

The differences in krotaphion-sphenion distances with respect to sex and origin analyzed in this study could be helpful in further research to improve the validity and practicability of sex and origin differentiation with respect to the pterion.

\section{Corresponding address}

\section{Dr. K. Jellinghaus}

Institute of Forensic Medicine, Julius-

Maximilians-University

Versbacher Str. 3, 97078 Würzburg, Germany

katharina.jellinghaus@gmail.com

Acknowledgements. The authors would like to acknowledge and thank Dr. Michael Francken, Prof. Matthias Graw, Dr. Stephanie Holley, Thomas Struchholz, Helmuth Schlereth, Thomas and Kevin Volk, Barbara Teßmann and Dr. Bernhard Heeb for providing the skull material thus making our investigations possible.

Funding. Open Access funding provided by Projekt DEAL.

\section{Compliance with ethical guidelines}

Conflict of interest. K. Jellinghaus, S. Matin, P. Urban, M. Bohnert and R. Jantz declare that they have no competing interests.

Ethical standards. All procedures performed in studies involving human participants or on human tissue were in accordance with the ethical standards of the institutional and/or national research committee and with the 1975 Helsinki declaration and its later amendments or comparable ethical standards. For all investigated skulls and skull collections informed consent was obtained from the persons responsible.

Open Access. This article is licensed under a Creative Commons Attribution 4.0 International License, which permits use, sharing, adaptation, distribution and reproduction in any medium or format, as long as you give appropriate credit to the original author(s) and the source, provide a link to the Creative Commons licence, and indicate if changes were made. The images or other third party material in this article are included in the article's Creative Commons licence, unless indicated otherwise in a credit line to the material. If material is not included in the article's Creative Commons licence and your intended use is not permitted by statutory regulation or exceeds the permitted use, you will need to obtain permission directly from the copyright holder. To view a copy of this licence, visit http://creativecommons.org/licenses/by/4.0/.

\section{References}

1. Krogman W, İşcan MY (1986) The human skeleton in forensic medicine. C.C. Thomas, Springfield

2. Herrmann B (2015) Prähistorische Anthropologie. Springer, Wiesbaden, $\mathrm{p} 18$

3. Adejuwon SA, Olopade FE, Bolaji M (2013) Study of the location and morphology of the pterion in adult Nigerian skulls. ISRN Anat. https://doi.org/ 10.5402/2013/403937

4. Gray H, Williams PL, Bannister LH (1995) Gray's anatomy: the anatomical basis of medicine and surgery. Churchill Livingstone, New York
5. Lama M, Mottolese C (2000) Middle meningeal artery aneurysm associated with meningioma. JNeurosurg Sci 44:39-41

6. Standring S, Gray H, Ellis H, Berkovitz KB (2005) Gray's anatomy: the anatomical basis of clinical practice. Elsevier, Churchill Livingstone

7. Eboh DEO, Obaroefe M (2014) Morphometric study of Pterion in dry human skull bones of nigerians. Int J Morphol 32:208-213. https://doi.org/10.4067/ S0717-95022014000100035

8. Lovejoy CO, Meindl RS, Mensforth RP, Barton TJ (1985) Multifactorial determination of skeletal age at death: a method and blind tests of its accuracy. Am J Phys Anthropol 68:1-14. https://doi.org/10. 1002/ajpa.1330680102

9. Knussmann R (1988) Anthropologie. Handbuch der vergleichenden Biologie des Menschen. Stuttgart, New York

10. Matin S (2020) Pterion als Merkmal zur Bestimmung von Geschlecht und Ethnizität unbekannter Schädelfunde. Julius-Maximilians-Universität, Wuerzburg

11. Verhoff M, Kreutz K (2004) Forensische Osteologie. Rechtsmedizin 14:417-430. https://doi.org/10. 1007/s00194-004-0271-5

12. LeopoldD(1998) Identifikation unbekannterToter: interdisziplinäre Methodik, forensische Osteologie (22) Schmidt-Römhild

13. Murphy $T$ (1956) The pterion in the Australian aborigine. Am J Phys Anthropol 14:225-244. https://doi.org/10.1002/ajpa.1330140218

14. Saxena SK, Jain SP, Chowdhary DS (1988) A comparative study of pterion formation and its variations in the skulls of Nigerians and Indians. Anthropol Anz 46:75-82

15. Asala SA, Mbajiorgu FE (1996) Epigenetic variation in the Nigerian skull: sutural pattern at the pterion East Afr Med J 73:484-486

16. Hauser G, De Stefano GF (1989) Epigenetic variants of the human skull. E. Schweizerbart'sche Verlagsbuchhandlung, Stuttgart

17. Gomez M (1998) Exchanging our country marks: the transformation of African identities in the colonial and antebellum south. University of North Carolina Press, Chapel Hill, London

18. Vivaan D, Shankar VV, Shetty S (2017) Morphometric study of pterion and asterion in adult human skulls of Indian origin. Int J Anat Res 5:3837-3842. https://doi.org/10.16965/ijar.2017.198

19. Wang Q, Opperman LA, Havill LM et al (2006) Inheritance of sutural pattern at the pterion in rhesus monkey skulls. Anat Rec Part A Discov Mol Cell Evol Biol 288A:1042-1049. https://doi.org/10. 1002/ar.a.20373

20. Abbie AA (1950) Closure of cranial articulations in the skull of the Australian aborigine. J Anat 84:1-12

21. Liu YH, Tang Z, Kundu RK et al (1999) Msx2 gene dosage influences the number of proliferative osteogenic cells in growth centers of the developing murine skull: a possible mechanism for MSX2mediated craniosynostosis in humans. Dev Biol 205:260-274. https://doi.org/10.1006/dbio.1998. 9114

22. Kim HJ, Rice DP, Kettunen PJ, Thesleff I (1998) FGF-, BMP- and Shh-mediated signalling pathways in the regulation of cranial suture morphogenesis and calvarial bone development. Development 125:1241-1251 